\title{
事例ベースを援用した知識洗練機能付 診断エキスパートシステムの開発
}

\author{
皆川 勝 ${ }^{1} \cdot$ 佐藤 茂 $^{2} \cdot$ 上谷 丈和 ${ }^{3}$
}

\begin{abstract}
'正会員 工博 武蔵工業大学助教授 工学部土木工学科( 158 -8557 東京都世田谷区玉堤 1-28-1)
²正会員 工修 株式会社 マエダ(テ163-0907 東京都新宿区西新宿 2-3-1)

3学生員 武蔵工業大学大学院 工学研究科 土木工学専攻(广158-8557 東京都世田谷区玉堤 1-28-1)
\end{abstract}

\begin{abstract}
エキスパートシステムの開発にあたっては，知識獲得の困難さがボトルネックであり，不確定情報を扱えること， 知識の更新機能をもつことが重要である. 本研究では, 仮説と仮説間の関係を構成要素とするネットワークで表現 された，ルールベース洗練機能付沉用型推論システムを構筑した．適用例として，道路橋 RC 床版の損傷要因推定 のための既存エキスパートシステムのルールベースを用いて, 提案するシステムの有効性を検討した．その結果, 適切な事例を教師データとして提示することによって，ルールベースが洗練され損傷要因推定の精度か顕著に向上 することが示された。
\end{abstract}

Key Words:expert-systems, knowledge acquisition,case base,diagnosis,network-systems

1.はじめに

エキスパートシステムを開発する上で最も解決が 困難な問題は，エキスパートが持っている問題解決能 力, 経験的な知識を陽な形式でルール化することに多 大な時間と労力を要し，しかも完全にそれを行うこと が容易でないことである ${ }^{1), 2)}$. そのため知識獲得をメ インに行うシステムの開発 ${ }^{1)}$, 過去に研究・開発され た豊富なエキスパートシステムの知識ベースを再利用 する方法 ${ }^{3)}$, 開発するエキスパートシステム中に知識 獲得機能をもたせる方法 4).5), 及び過去の事例を用い て提示された問題解決する事例べース推論の研究 6), が活発に行われている.

また，経験的なノウハウをルール化するためには， 不確定な情報を取り扱い得ることが, 必須条件である. 更に，不確定な知識を取り扱う場合には，その不確定 さ故に，知識の更新機能をもつことが重要視されてき た。

一方，土木工学の分野では，維持管理，施工管理, 構造計画及びデー夕解析など多様な役割をになう技術 者を支援するために, 解析, 診断, モニターリング, 予測，計画及び設計などを対象とする，エキスパート システムが多数開発されてきた.

中村らは水力鋼構造物の寿命予測のために前向き
推論と後向き推論の機能をもつプロダクションシステ ムを構筑した ${ }^{8), 9}$. ここでは, 主観的なデー夕値に対 して，個々のスコアを計算し，その重み付き平均を用 いて相互的な判断を行うという方法で不確定さを取り 扱った。 また, ルールベースは，システムを利用評価 していく過程で追加及び修正して行くものとしている が，具体的な方法は示していない.

白石・古田らは過去の設計例のデータから概念毎 にデー夕を分類し，ルールを生成する設計支援エキス パートシステムを構築した ${ }^{5)}$.また，推論過程におい ては, 言語評価値を扱うためファジィ理論を用いた。

串田・宮本は,コンクリート橋診断ファジィ・エキ スパートシステムにおいて, メンバーシップ関数及び 影響度を変更することで, 知識を洗練する方法を提案 し ${ }^{4)}$ ，また，宮本らはニューラルネットワークを用い たルールの更新や連想記憶を組み合わせた不確定さを もつ推論方法を提案した ${ }^{10}$. 更に, 宮本らは可能性 や必然性の概念をファジイ理論を適用した知識表現手 法に導入し, 知識の洗練度を考慮した知識更新方法を 提案した ${ }^{11)}$.

三上らは，鋼橋疲労補修方法選定システムを因果 ネットワークで表現し，これにニューラルネットワー クを用いて学習機能を付加する方法 ${ }^{12}$, 未定義の因 
果関係を自動的に生成して知識ベースのルールを獲得 する方法などを提案した ${ }^{13), 14)}$. 更に, 田中・三上ら は, 推論精度の向上のためにルールベース推論と事例 ベース推論を併用したシステムを構築した ${ }^{6,15)}$.

このように, アンケート等による通常の方法から， 個々の事実から一般的な規則を導き出す帰納的な推論 方法や, 事例ベース推論のように, 過去の事例を直接 利用して解を導く等, 設計例などのいわゆる個別の事 例からルールを生成する方法へと, 知識獲得手法は発 展しつつある.しかし, 事例べース推論においては, ルールベースシステムで必要なルールを必要としない という利点はあるが, 事例ベースを構築する際に, 事 例を特徵付けるための索引群によって構成される, シ ステムのための事例構造を獲得する必要が生じ, これ が知識獲得問題に代わり, 事例構造獲得問題として, 新たな問題となってくる等の課題もあり, 実用化には 至っていない.

また、これまで構築されてきたエキスパートシス テムは, 様々な知識表現手法を用いており, 知識の共 有化あるいは再利用という観点からは, 既存システム による推論結果を容易に反映してルールベースを再構 築できる方法論を確立することは重要である.

そこで本研究は, 現状では, 推論方法としては, ルールベース推論が最も多用されていると考えられる ことから，ルールベースを基本として, 汎用的な相互 結合ネットワークで推論システムを構成し, 既存シス テムの推論結果を教師データとして提示することによ って，ルールベースを洗練するアルゴリズムを提案し た.これにより, 既存システムとほほ同じルールベー ス推論が可能で, 教師データとして示された事例に合 致するような因果関係の強さをきわめて容易に陽な形 で求めることができるばかりでなく, 将来的には, 複 数のルールベースシステムの統合へと発展させること ができる. 応用例として, 三上・田中らの道路橋 RC 床版の損傷要因推定のためのルールベースに提案アル ゴリズムを適用して,ルールベースを洗練するための 教師デー夕の提示方法による影響を含め, 本システム の有効性を検討した。

\section{2. 提案する知識洗練機能付診断エキスパート システム}

\section{(1) 提案するシステムの概要}

本研究では, 仮説と仮説間の関係を構成要素とす る相互結合ネットワークで表現されたルールベース洗 練機能付汎用型推論システムを構築した。 ここで述べ る相互結合ネットワークは, 知識を相互に結合してネ ットワークで表現することである. したがって, 因果
関係が存在し得る仮説間の関係のみを結合してネット ワークを構成する. 本推論システムは, アンケート用 紙に従って解答してもらうなどの従来の方法で獲得さ れたエキスパートの知識をルール化することにより通 常の推論を行えるばかりでなく, 具体事例に対する既 存システムの推論結果を教師データとして用いること によって，ルールベースを洗練することができる.

ここで述べる事例とは, 前例となる事例のことであ る. 通常, 後に発生する問題に対処するためにある事 例を参考とする場合には，その事例を䛊りを含む可能 性のない事実として用いるよりも, 誤りを含む可能性 のある過去の経験的事実として考慮される. 経験的事 実であれば, どの程度信頼してよいかの判断が必要に なることは言うまでもない.

そこで, 本推論システムでは, ルールベースが事 例すなわち教師デー夕より信頼度が高い場合には，い わゆる min-max 合成による推論を行う。また, ルー ルベースの信頼度に比べて高い教師データが得られて いる場合には，階層型ニューラルネットワークで用い られる誤差逆伝播の概念を応用して教師データに対応 するようにルールベースを洗練する．ここで，上述の 信頼度をどのように設定するかは, 重要な問題である. 本研究では, 高度の専門知識を持つ技術者と知識技術 者が判断して設定すべきものとしてとらえている.

\section{(2)仮説間の関係及び仮説の数值表現}

本研究で構築した推論システムでは, ネットワー クを構成するノード及び結合がそれぞれ仮説及び仮説 間の関係を示している. それらの属性值は, 仮説の成 立する可能性(以後, ”ノード值”と呼ぶ.) 及び仮説間 の関係の強さ(以後, "結合係数”と呼ぶ. )であり,こ れらを区間 $[0,1]$ の実数値で表現している. 更に, ， 一ド值及び結合係数に対して確信度を付与し, それら の確信度をノード確信度及びルール確信度と呼ぶ.ま た, 各ノードは, 過去の事例から得られる教師デー夕 をもつことができる. 教師デー夕は, 各仮説の属性值 である[ノード値, ノード確信度]に対応して[ノード教 師値, ノード教師確信度]を属性值としてもつ.この 確信度を付与することにより，不確定さを表現できる ばかりではなく，仮説推論及びルールベース洗練の 2 つの機能を併せもつ本推論システムの動作もまた制御 することができる.すなわち，推論を実行する前の事 前情報として, ルールの属性值としての[結合係数, ルール確信度]及びノードの教師データの属性值とし ての[ノード教師值, ノード教師確信度があり，それ によって[ノード值，ノード確信度]を得たり，[結合係 数、ルール確信度]を更新することになる。 


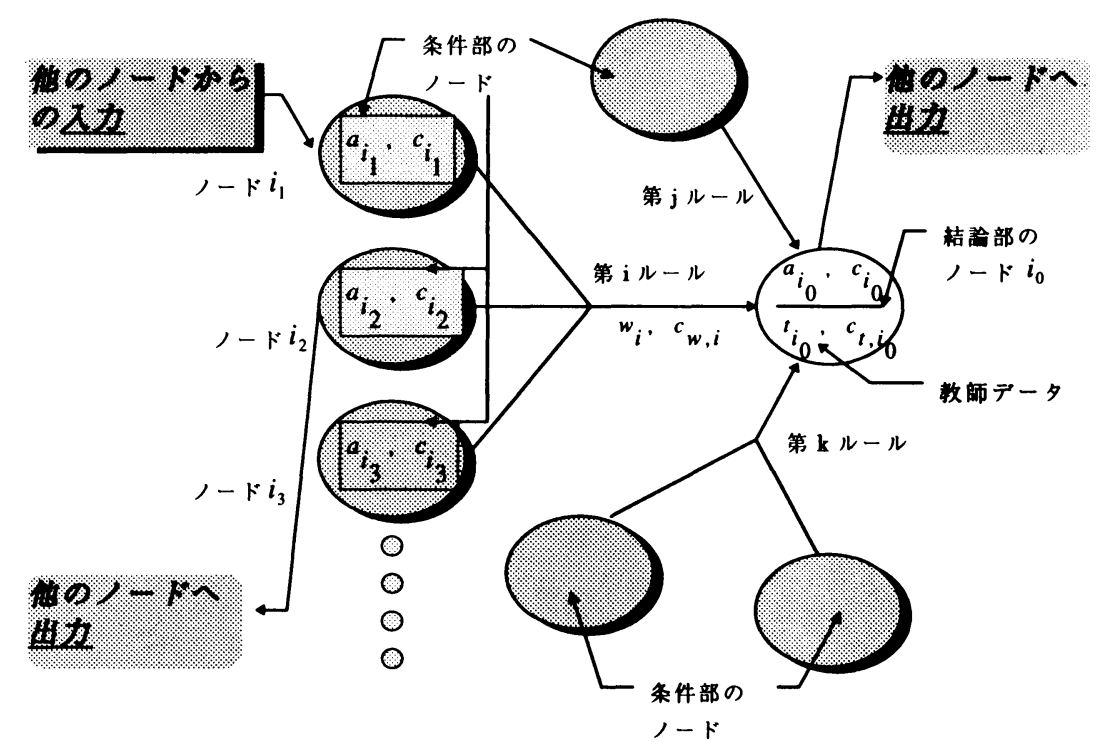

図-1 本推論システムの全体構成

(3)推論アルゴリズム

本推論システムの全体構成を図-1 に示す．各ルー ルは複数の条件部を持ちうることとした．図-1中の

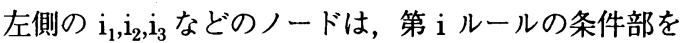
示し，また， $\mathrm{i}_{0}$ ノードは同じルールの結論部を表し

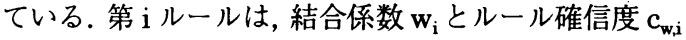
で定義されている．また，それぞれのノードは，ノー ド值 $\mathrm{a}_{\mathrm{il}}$ 及びノード確信度 $\mathrm{c}_{\mathrm{il}}$ で定義されるものとする. 図-1 の例では，第 $i, j, k$ のルールが同一のノードを 結論部としてもっている，それぞれのノードは，ある 場合は，他のノードへの入力(すなわち条件部)となり， ある場合には他からの出力(すなわち結論部)となり得 る. 以下で，これらの属性值を用いた推論アルゴリズ ムを示す。

まず，ある一つのルールから導かれるノード值を 次の式(1)のようにいわゆる $\min$ 演算により求める.

$$
\bar{a}_{i}=\wedge\left(\hat{l}_{i_{l}}, w_{i}\right)
$$

また，同じルールから導かれる確信度を次の式(2) により求める。

$$
\bar{c}_{i}=c_{i_{l}} \cdot c_{w, i}
$$

あるノードがただ一つのルールの結論部となって いる場合には, 式(1)及び(2)で求まる值が結論部のノ ード値とノード確信度となる。

$$
a_{i_{0}}=\bar{a}_{i}
$$

$$
c_{i}=\bar{c}_{i}
$$

あるノードが 2 つ以上のルールの結論部となって いる場合には，それらのルールについて式(1)及び(2) から得られた値を次の式(5)及び(6)を用いて統合して, その結論部のノード值及びノード確信度を求める.

$$
\begin{gathered}
a_{i_{0}}=\underset{m}{v}\left(\bar{a}_{m}\right) \\
c_{i_{0}}=\dot{+}\left(\bar{c}_{m}\right)
\end{gathered}
$$

ここで, $+\dot{+} a+b=a+b-a \cdot b$ を示す記号であ $\eta, \dot{+}()$ は $c_{m_{1}}+c_{m_{2}}$ for $\forall m_{1}, m_{2} \in m$ であることを示す。

(4)洗練アルゴリズム

図-1 に示したように，各ノードは教師データをも つ.教師データは全ノードについてノード教師値及び ノード教師確信度の対で定義される.

通常のルールベース・システムの推論は, ルール ベースを確定情報としてもち，これからある特定な事 例に対する仮説の状態を推定することになる，本推論 システムでは, ノード教師確信度がルール確信度より 低い場合に，このような推論が行われるものとしてい る.また，確信度の高い情報としての事例を持つ場合 には，ルール確信度がノード教師確信度に比べて低く なり,ルールベースが洗練されることになる。 
例えば，ルール確信度を“1.0”に設定し, 求める ノードのノード確信度を“0.1”等の低い值に設定す ればノード值がルールベースにより求められることに なる，反対に，ルール確信度を“0.1”に設定し，ノ ード確信度を“1.0”にすれば，ルールベースが洗練 されることになる。また，より一般的な場合には，ル 一ル確信度とノード教師確信度の大小により, 同時進 行的にルール洗練とノード值更新がなされる.以下に, ノード確信度とルール確信度の大小関係から, 仮説と ルールベースを洗練(すなわち，ノード值及び結合係 数を更新)するアルゴリズムを示す.

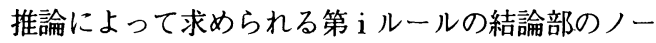
ド確信度と, 同じノードに与えられたノード教師確信 度を比較し，ノード確信度またはノード教師確信度の 低い方のノード值を更新する．まず，推論によって求 まったノード值及びノード教師值，ノード確信度及び ノード教師確信度の差を次の式(7)及び(8)より求める.

$$
\begin{gathered}
{ }_{i_{0}}=a_{i_{0}}-t_{i_{0}} \\
\Delta c_{i_{0}}=c_{i_{0}}-c_{t, i_{0}}
\end{gathered}
$$

ここで, $\Delta c_{i_{0}} \geqq 0$ なら, 教師データが確信度の低い 情報と見なされ次の式(9)及び(10)によりノード教師値 及びノード教師確信度が更新される.

$$
\begin{aligned}
& { }_{i_{0}} \leftarrow{ }_{i_{0}}+\eta \cdot \Delta a i_{0} \\
& c_{t, i_{0}} \leftarrow c_{t_{1, i_{0}}}+\eta \cdot\left|\Delta c_{i_{0}}\right|
\end{aligned}
$$

ここで, $\eta$ は学習率である. $\Delta c_{i_{0}} \mid<0$ の場合, 実行 された推論における min-max 演算において採用され

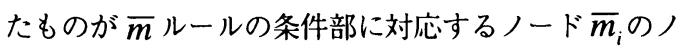
ード值であるならば，そのノードに対応するノード值 及びノード確信度が次の式(11)及び(12)を用いて更新 される.

$$
\begin{aligned}
& a_{\bar{m}_{\bar{l}}} \leftarrow a_{\bar{m}_{\bar{l}}}+\eta \cdot \Delta a_{i_{0}} \\
& c_{\bar{m}_{\bar{l}}} \leftarrow c_{\bar{m}_{\bar{l}}}+\eta \cdot\left|\Delta c_{i_{0}}\right|
\end{aligned}
$$

また, min-max 演算により採用されたものが ールの結合係数であるなら，そのルールの結合係数と ルール確信度が次の式(13)及び(14)を用いて更新され る.

$$
w_{\bar{m}} \leftarrow w_{\bar{m}}+\eta \cdot \Delta a_{i_{0}}
$$

$$
c_{w, \bar{m}} \leftarrow c_{w, \bar{m}}+\eta \cdot\left|\Delta c_{i_{0}}\right|
$$

この方法は, 階層型ネットワークの学習アルゴリ ズムである誤差逆伝播法に類似した方法であり，推論 は，観測や経験によって既知の事前情報に対応したノ 一ドから始まって，ノード間の結合をたどる，入力を 持つノードではすべての入力からの情報がそろったと ころで推論し，順次下流側の結合へ推論が続く。この 流れは最終的に出力を持たないノードまで行って終了 する. その後, この推論結果と教師デー夕を用いて, 再度, 上述の既知情報に対応したノードから出力を持 たないノードまで,ノードの各属性，または結合の各 属性が更新される．このプロセスを各属性值が変化し なくなるまで繰り返し，ある一定の值に到達した時点 で解を提示する．相互結合型のニューラルネットワー クの場合には, 完全結合で外からの入力がない場合に は安定状態を持つことが知られている ${ }^{16)}$. 一方, 本 研究で用いているネットワークは，外からの入力を持 ち，また不完全結合である。したがって,安定状態が 存在しない場合が考えられる。しかし，提案システム では仮説と結合に確信度が付与されており，これがシ ステムを安定して収束させる作用をしており，後述の 適用例においても解が発散する現象はまったく見られ ていない.

本アルゴリズムの特徵は, 本来ブラックボックスで あるニューラルネットワークにおける学習アルゴリズ ムの考え方を，1つ1つの結合が具体的なルールを表 すネットワークに対して適用している点にある。した がって, ニューラルネットワークでは, 全結合である ために入出力関係を柔軟に表現できるものの，その関 係は明示的でなく陰な形でルールを獲得するのに対し， 本システムでは，ルール洗練により陽な形で具体的な ルールの重要度を獲得することができる。この点にお いて，ニューラルネットワークと本システムとは，本 質的に利用目的が異なっている.

更に，各仮説の成立する可能性及び仮説間の関係の 強さに加えて, それらの信頼度を示す確信度を付与し た点も特徵である. 現段階では, この確信度は, 前述 のように高度の専門技術者の判断により設定すること にしているが，将来的には，情報理論的なアプローチ により客観的に設定できるようにすることが望ましい が, 本論文では, この問題には深く立ち入らない。

\section{3. 適用した診断エキスパートシステム ${ }^{17}$}

適用したルールベースは, 三上・田中らにより開発 された道路橋 RC 床版の損傷要因推定エキスパートシ 


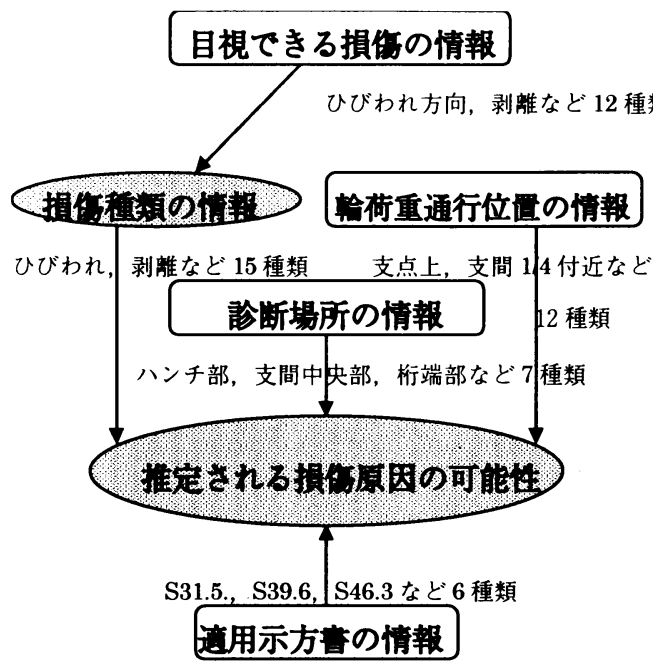

図-2 診断エキスパートシステムの概要 ${ }^{17)}$
表-1 推定対象とする損傷要因 ${ }^{171}$

\begin{tabular}{|c|c|}
\hline 荷重 & 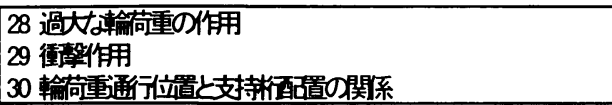 \\
\hline $\begin{array}{c}\text { 設計 } \\
\cdot \\
\text { 構造与 }\end{array}$ & 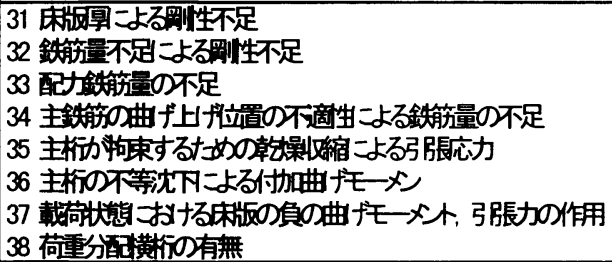 \\
\hline 施工 & 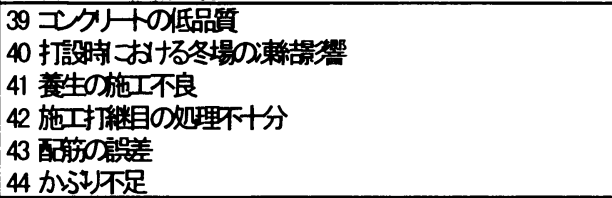 \\
\hline D他 & 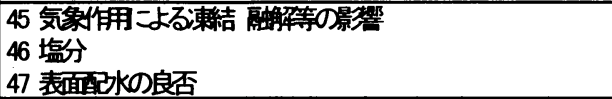 \\
\hline
\end{tabular}

表-2 提示する事例 ${ }^{17)}$

\begin{tabular}{|c|c|c|c|c|c|}
\hline \multicolumn{2}{|c|}{ 事象 事例 } & 事例1 & 事例 2 & 事例 3 & 事例 4 \\
\hline \multirow{3}{*}{ 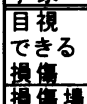 } & ひひわれ & 棈方向 & 綂横方向 & 絃栱方向 & 綎横方向 \\
\hline & 剩离" & - & - & - & - \\
\hline & 还綪の流出 & 迤祸石灰 & 淮部石灰 & 游噰石灰 & 遊離石灰 \\
\hline \multicolumn{2}{|c|}{ 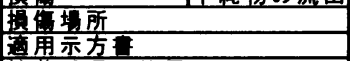 } & ハンチ部付近 & $\begin{array}{l}\text { 支闻中央部付近 } \\
\text { 昭和 } 39 \text { 年3月示方 }\end{array}$ & $\begin{array}{c}\text { 析端部 } \\
\text { 昭和 } 39 \text { 年3月示方: }\end{array}$ & \begin{tabular}{|l|} 
ハンチ部付近 \\
昭和 42 年 9 月示方意
\end{tabular} \\
\hline \multicolumn{2}{|c|}{ 荷夏通行位量 } & 支自1/4付近 & - & - & 支間 $1 / 4$ 付近 \\
\hline
\end{tabular}

\begin{tabular}{|c|c|c|c|c|c|}
\hline \multicolumn{6}{|c|}{ 事象例 } \\
\hline \multirow{3}{*}{ 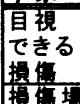 } & ひひわれ & 再楨方向 & 綎横方向 & 篮横方向 & 維横方向 \\
\hline & 制部 & - & - & 莩き有り & - \\
\hline & 不純物の流出 & 避踓石灰 & 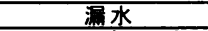 & - & - \\
\hline \multirow{2}{*}{\multicolumn{2}{|c|}{ 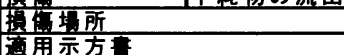 }} & ハンチ部付近 & ハンチ部付近 & ハンチ部付近 & ハンチ部付近 \\
\hline & & 昭和55年2月示方 & 昭和39年3月示方: & 昭和 39年3月示方 & 昭和 39年3月示方 \\
\hline \multicolumn{2}{|c|}{ 河票通行位 } & 支间 $1 / 4$ 付近 & 支间 $1 / 4$ 付近 & 支間 $1 / 4$ 付近 & 支間 $1 / 4$ 付近 \\
\hline
\end{tabular}

表-3 既存システムにおけるハンチ部付近の損傷要因と損傷種類 ${ }^{17)}$

\begin{tabular}{|c|c|}
\hline ひひわれ & $\begin{array}{ll}13 & \text { 橋軸方向 } \\
14 & \text { 幅員方向 } \\
15 & \text { 縰横方向 } \\
16 & \text { 格子状 } \\
17 & \text { 亀甲状 } \\
18 & \text { 通 }\end{array}$ \\
\hline 剥離 & $\begin{array}{|ll|}19 & \text { 浮き有り } \\
20 & \text { かぶり欠落 } \\
21 & \text { 破壊 } \\
\end{array}$ \\
\hline & 22 遊離石灰流出 \\
\hline & 23 漏水 \\
\hline $\begin{array}{l}\text { 鉄筋 } \\
\text { 簬出 }\end{array}$ & $\begin{array}{ll}24 & \text { かぶり不足 } \\
25 & \text { 剥離 }\end{array}$ \\
\hline & 26 鉄筋発錆 \\
\hline & 27 鉄筋度食 \\
\hline
\end{tabular}

\begin{tabular}{|c|c|c|c|c|c|c|c|c|c|c|c|c|c|c|c|c|}
\hline \multirow{2}{*}{\multicolumn{2}{|c|}{ 要因 }} & \multicolumn{6}{|c|}{ ひびわれ } & \multicolumn{3}{|c|}{ 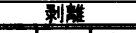 } & \multirow[b]{2}{*}{22} & \multicolumn{3}{|c|}{ 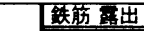 } & \multirow[b]{2}{*}{26} & \multirow[b]{2}{*}{27} \\
\hline & & 13 & 14 & 15 & 16 & 17 & 18 & 19 & 20 & 21 & & 23 & 24 & 25 & & \\
\hline \multirow{3}{*}{ 荷重等 } & 28 & 0 & $\Delta$ & 0 & 0 & 0 & 0 & 0 & 0 & (2) & & 0 & & (a) & & \\
\hline & 29 & $\Delta$ & $\overline{0}$ & ठँ & 0 & 0 & 0 & 0 & 0 & 0 & & $\Delta$ & & 0 & & \\
\hline & 30 & & & & & & & & & & & & & & & \\
\hline \multirow{8}{*}{$\begin{array}{c}\text { 設計 } \\
\dot{0} \\
\text { 搆造上 }\end{array}$} & 31 & 0 & 0 & o & . & 9 & 9 & 0 & 0 & (a) & 0 & 9 & & (0) & & \\
\hline & 32 & (2) & 0 & $\odot$ & 0 & 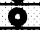 & 9 & 0 & 0 & (2) & 0 & 0 & & (2) & & \\
\hline & 33 & (2) & \% & 6 & 0 & C) & क) & 0 & 0 & 0 & o & 0 & & 0 & & \\
\hline & 34 & (2) & $\Delta$ & 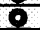 & คे & ० & 0 & 0 & 0 & (2) & & 0 & & (0) & & \\
\hline & 35 & & & & & & & & & & & 0 & & & & \\
\hline & 36 & & 0 & 0 & 0 & 0 & 0 & & & & & & & & & \\
\hline & 37 & & 0 & 0 & 0 & 0 & 0 & & & 0 & 0 & $\Delta$ & & & & \\
\hline & 38 & & 0 & 0 & 0 & 0 & 0 & & & $\Delta$ & $\Delta$ & $\bar{\Delta}$ & & & & \\
\hline \multirow{6}{*}{ 施工上 } & 39 & $\Delta$ & $\Delta$ & $\Delta$ & $\Delta$ & $\Delta$ & $\Delta$ & $\Delta$ & $\bar{\Delta}$ & $\Delta$ & & $\Delta$ & & $\Delta$ & $\Delta$ & $\Delta$ \\
\hline & 40 & $\Delta$ & $\Delta$ & $\Delta$ & $\Delta$ & $\Delta$ & $\Delta$ & $\Delta$ & $\Delta$ & $\Delta$ & & $\Delta$ & & $\Delta$ & $\Delta$ & $\Delta$ \\
\hline & 41 & $\Delta$ & $\bar{\Delta}$ & $\Delta$ & $\Delta$ & $\Delta$ & $\Delta$ & $\Delta$ & $\Delta$ & $\overline{0}$ & & $\Delta$ & & $\Delta$ & $\Delta$ & $\Delta$ \\
\hline & 42 & & $\Delta$ & $\Delta$ & $\Delta$ & $\Delta$ & $\Delta$ & 0 & $\bar{O}$ & 0 & 0 & 0 & 0 & 0 & 0 & 0 \\
\hline & 43 & $\Delta$ & $\Delta$ & $\Delta$ & $\Delta$ & $\Delta$ & $\Delta$ & $\Delta$ & $\Delta$ & $\Delta$ & & & 0 & 0 & 0 & 0 \\
\hline & 44 & & $\bar{\Delta}$ & $\bar{\Delta}$ & $\bar{\Delta}$ & $\bar{\Delta}$ & $\Delta$ & $\overline{0}$ & $\bar{O}$ & $\overline{0}$ & & & () & (2) & 0 & 0 \\
\hline \multirow{3}{*}{ その他 } & 45 & & $\Delta$ & $\Delta$ & $\Delta$ & $\Delta$ & $\Delta$ & & & & & & & & & \\
\hline & 46 & & & & & & & & & & & & & $\Delta$ & 0 & 0 \\
\hline & 47 & & & & & $\Delta$ & $\Delta$ & & & $\Delta$ & 8 & 0 & & $\Delta$ & 0 & 0 \\
\hline
\end{tabular}

ステム(以後, "既存システム”と呼ぶ.) )ルールベー スである，既存システムは，確信度付きのプロダクシ ヨンシステムを用いて，道路橋 RC 床版の損傷状況か ら損傷要因を推定するものである。すすおち図-2 に 示すように, 目視できる損傷から損傷種類を求め, 求 められた損傷種類, 輪荷重通行位置, 適用示方書及び
損傷場所から損傷要因を推定するものである．推定の 対象とする損傷要因を表-1 に示す。更に，既存シス テムに提示される入力情報を表-2 に示す.

ルールベースは, 目視できる損傷-損傷種類, 損傷 種類-損傷要因, 適用示方書-損傷要因及び損傷場所-損 傷要因の因果関係からなる。それらは文献[17]から引 
表-4 既存システムの推論結果 ${ }^{17)}$

\begin{tabular}{|c|c|c|c|c|c|c|c|c|c|c|c|c|c|c|c|c|c|c|c|c|}
\hline 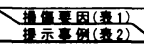 & 28 & 29 & 30 & 31 & 32 & 33 & 34 & 35 & 36 & 37 & 38 & 39 & 40 & 41 & 42 & 43 & 44 & 45 & $46 \quad$ & \\
\hline 例 & 073 & 0.73 & 0.92 & 09 & 0.88 & \begin{tabular}{|l|}
092 \\
\end{tabular} & 085 & 04 & 071 & \begin{tabular}{|l|}
077 \\
\end{tabular} & 074 & 032 & $\begin{array}{ll}032 \\
\end{array}$ & 032 & 055 & 038 & 038 & 024 & 0.18 & 0.58 \\
\hline 侄 & 0.9 & 077 & 0.5 & 0.73 & 0.73 & 0.6 & 03 & 0.4 & 0.59 & 0.65 & 06 & 0.4 & 0.52 & 0.56 & 058 & 0.1 & 0.2 & 01 & 0 & \\
\hline 伍 & 0.86 & 0.86 & 0.47 & 0.76 & 0.86 & 0.85 & 0.3 & 0.33 & 0.31 & 0.31 & 0.31 & 0.37 & 0 & $\begin{array}{l}0.5 \\
\end{array}$ & 0 & 048 & 054 & 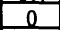 & 0 & 0.75 \\
\hline 侄 & 073 & 0.73 & 0.92 & 09 & 0.88 & 089 & 0.85 & 04 & 0.71 & 0.77 & 0.74 & 0.32 & 0.32 & 0.32 & 0.55 & 38 & 38 & 024 & 0.18 & 0.58 \\
\hline 例 & 0.73 & 0.73 & 0.92 & 0.85 & 0.83 & 0.89 & 0.78 & 0.16 & 0.59 & 077 & 0.63 & 0.32 & $\begin{array}{ll}0.32 \\
\end{array}$ & 032 & 0.55 & 10.38 & 6.38 & 0.24 & 0.18 & 0.58 \\
\hline 俉 & 0.73 & 0.73 & 0.9 & 0.88 & 0.86 & 0.9 & 0.85 & 0.4 & 0.72 & 0.73 & 0.73 & 0.32 & 0.32 & 0.32 & $\begin{array}{l}0.48 \\
\end{array}$ & 0.38 & 0.38 & 0.24 & 0.18 & 0.45 \\
\hline 国 & 0.72 & 0.72 & 0.88 & 0.85 & 0.85 & 0.86 & 0.85 & 0.3 & 0.68 & 0.68 & 0.68 & 0.25 & 0.25 & 025 & 0.35 & 0227 & 0.35 & 0.2 & 0.35 & 0.1 \\
\hline 歖 例 & 0.53 & 53 & 65 & 265 & 65 & 265 & 265 & 0.3 & 53 & 253 & 0.53 & 12 & 12 & 12 & 212 & 212 & 012 & 12 & 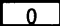 & \\
\hline
\end{tabular}

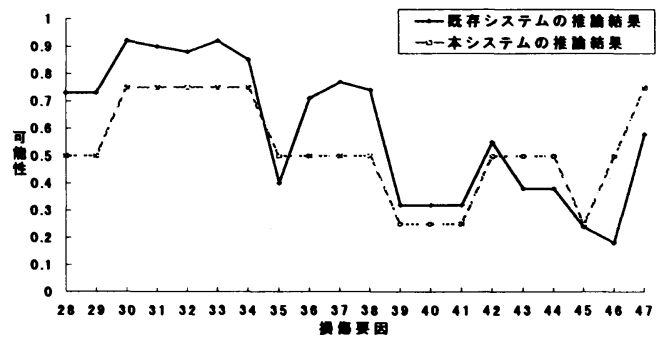

図-3 事例 1 の損傷要因の可能性(ルール洗練なし)

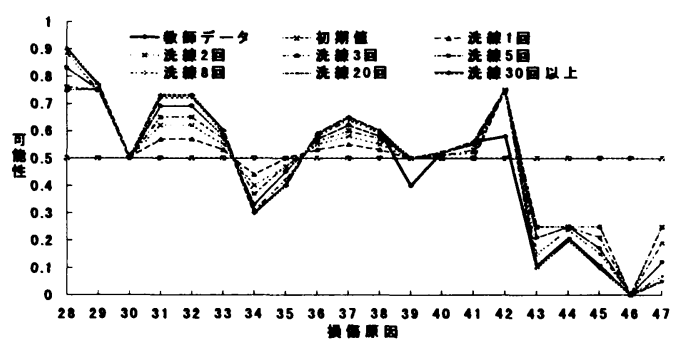

図-5 事例 2 の損傷要因の可能性

(単独事例によるルール洗練後)

用した。例として，ハンチ部付近の損傷種類-損傷要 因の因果関係を表-3 に示す。，○，வはそれぞれ 確信度が 0.5，0.3，0.1 であることを表している．三 上・田中らは，あいまいな知識を記述するのであるな らば，あまり細分化しても無意味であると考え， 3 段 階としたものであり，確信度の計算には MYCIN に よる方法を用いた。

本研究では既存システムのルールベースにおける確 信度 $\bigcirc ， \bigcirc ， \Delta$ に対応させてそれぞれ $3 / 4 ， 2 / 4 ， 1 / 4$ の值をルールの結合係数として与えた. 既存システム の確信度に比べて結合係数が大きいのは，2. (3)で述 べたように推論が min-max 演算に基づいていることに よるものである．用いるノードすなわち仮説の総数は 63, ルール数は 872 である. 更に, 既存システムを用 いて表-2 の事例に対して推論した結果を表-4 に示し た. 表中の番号 28４7 は表-1 の損傷要因番号を示す.

\section{4. ルールベース洗練前の損傷要因の推定}

はじめに, ルールベースを確定情報とし，損傷要因 の可能性を推定した。用いた事例は，表-2 に示した

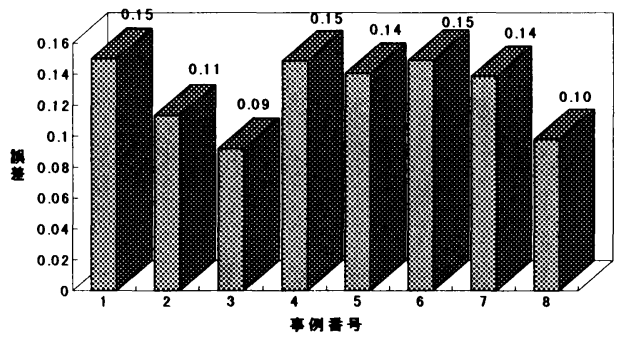

図-4 既存システムと本システムにより求めた 損傷要因の可能性の誤差 (ルール洗練なし)

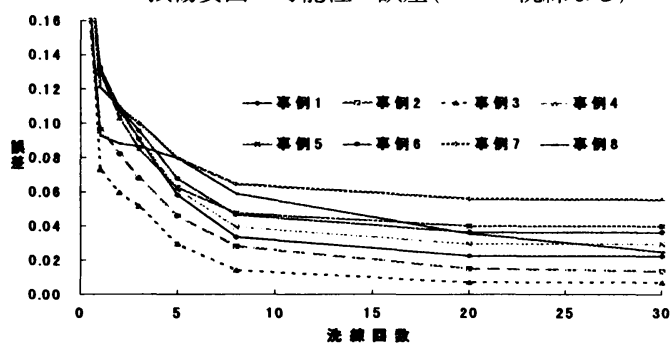

図-6 誤差と洗練回数の関係

（単独事例によるルール洗練後）

ものである. 例として, 図-3に事例 1 の推論結果と 教師データを, 損傷要因の可能性を縦軸に, 損傷要因 のノード番号を横軸にとって示した．ここでいう，教 師データとは, 表-4に示した, 各事例に対して既存 システムが推論した損傷要因の可能性である. 更に, 教師データと本システムによる推論結果との誤差を次 の式(15)により求め, 縦軸に誤差, 横軸に事例番号を とって図-4に示した。

$$
\text { 誤差 }=\frac{\sum_{i}\left|t_{i}-a_{i}\right|}{n}
$$

ここで， $t_{i}$ は既存システムにより求まった第 $\mathrm{i}$ 損 傷要因の可能性, $\mathrm{a}_{\mathrm{i}}$ は本推論システムにより求まった 第 $\mathrm{i}$ 損傷要因の可能性を示しおり, $n$ は対象としてい る損傷要因の個数を表している.

これらの結果で, 既存システムと本システムの推 論結果に相違が現れた原因は，既存のルールベースを 移植する際に用いた $3 / 4 ， 2 / 4 ， 1 / 4$ という結合係数に 明確な根拠が必ずしもないこと，推論過程において min-max 演算を用いていることがあげられる.しかし， 傾向としては, 事例 1 以外も含めて損傷要因の可能性 

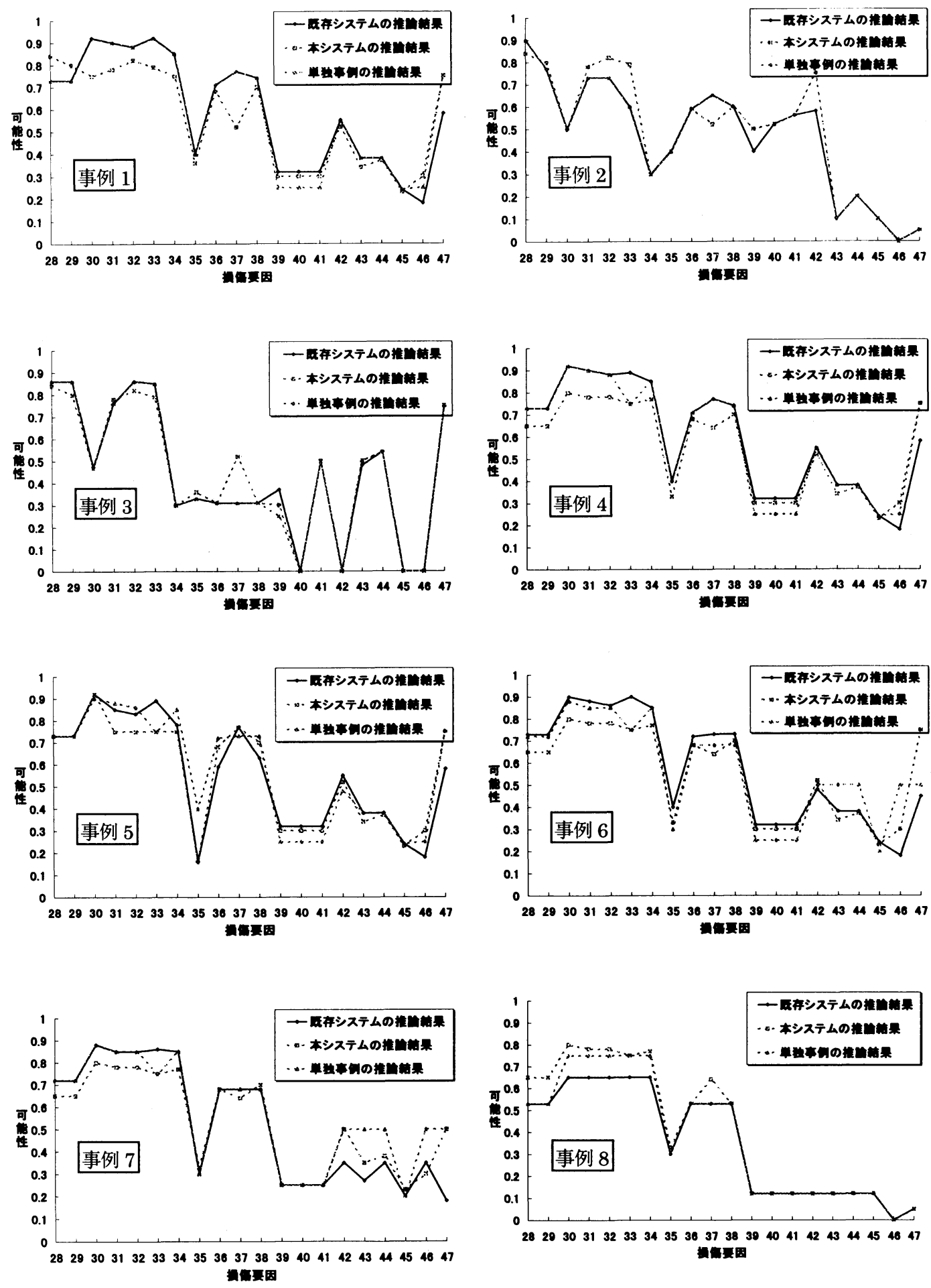

図-7 各事例の損傷要因の可能性 (8 事例の同時提示) 


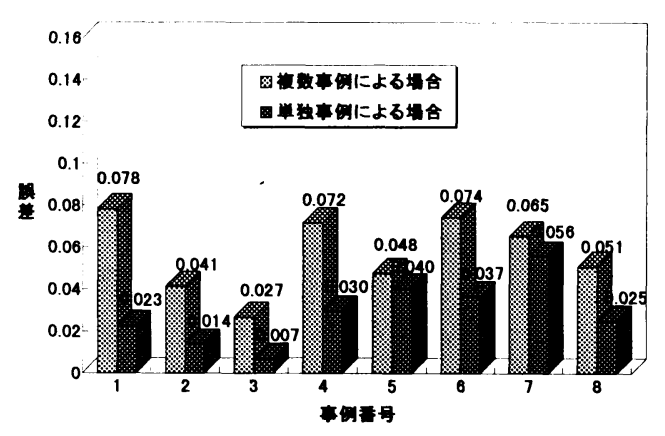

図-8 既存システムと本システムにより求めた 損傷要因の可能性との誤差 (8 事例の同時提示)

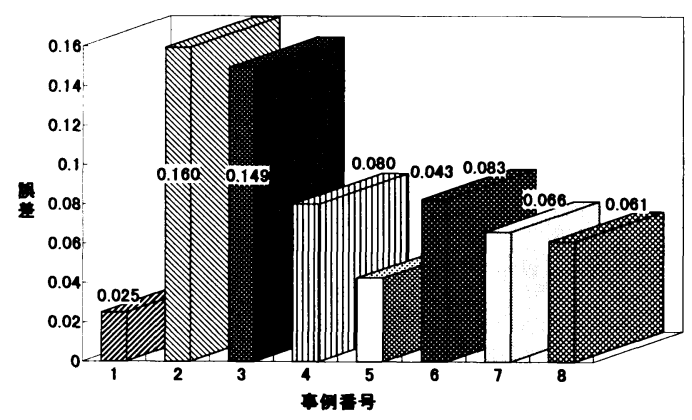

図-10 既存システムと本システムにより求めた 損傷要因の可能性との誤差 (損傷場所が同一の 6 事例を同時提示)

の大小の分類において比較的良く一致している.

\section{5. ルールベース洗練後の損傷要因推定}

既存システムの推論結果を確定的な情報とみなし, これを教師データとして提示して,ルールベースを洗 練し，その後，洗練されたルールベースを用いて損傷 要因を推定した.ただし，ルールベースの洗練途中に おいて教師データが変化しないように，すべてのノー ド教師確信度を“1.0 “にし，またすべてのルール確 信度を” 0.1 “に設定した．更に，損傷要因を推定す る際には，ルールベース洗練後のルール確信度をその まま用い，損傷要因の可能性は未知情報であることか らノード值及びノード確信度をそれぞれ” 0.5 “及び” 0.1 “とした. 教師データは表-2 及び 4 に示した既存 システムの推論結果である.

\section{（1）単独事例を用いたルール洗練}

はじめに, 事例 1 から事例 8 の教師デー夕を各々 単独に提示し, ルールベースの洗練を行った. 例とし て, 事例 2 の結果を, 損傷要因の可能性を縦軸に, 損

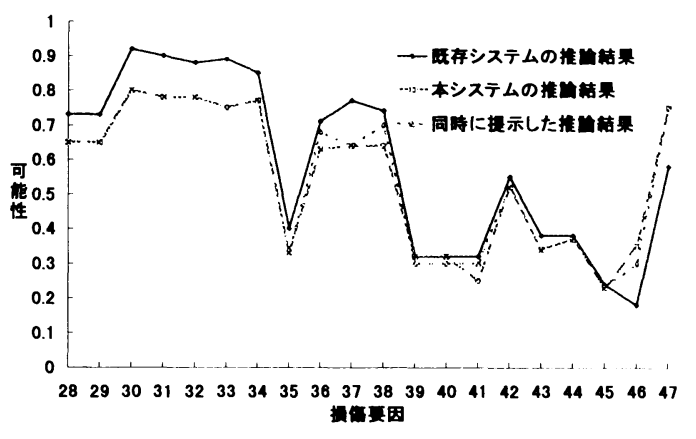

図-9 事例 4 の損傷要因の可能性

(損傷場所が同一の 6 事例を同時提示)

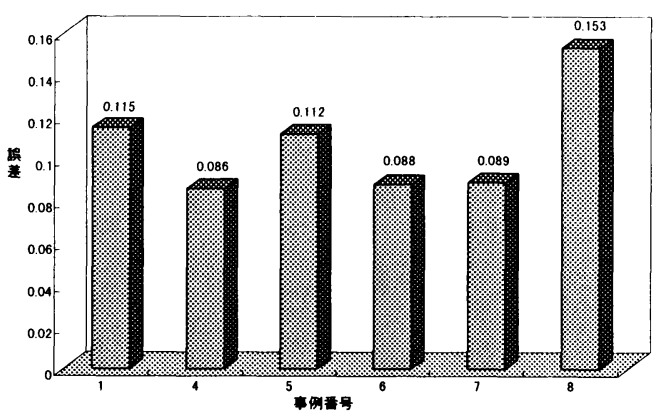

図-11 既存システムと本システムにより求めた 損傷要因の可能性との誤差 （損傷場所が同じ未提示事例の推定）

傷要因のノード番号を横軸にとり, 図-5 に示した. また，図中には，洗練における反復回数(以後，”洗練 回数”と呼ぶ.)の影響を見るため, 洗練回数が異なる 場合の結果も示した。 また, 比較のために教師データ も示した. 更に, 式(15)により各事例の誤差を算定し, 誤差と洗練回数の関係を図-6に示した.

これらの結果から, 単独事例を提示してルールベー スを洗練すると, 各事例の推論結果が教師データとほ ほ一致することが分かった。 しかし，単独事例によ るルール洗練ということは, 各事例に対して異なるル ールを求めることになるため, 実用上の価値は低い. そこで, 次節では複数事例を用いてルールを洗練する.

\section{（2）複数事例を用いたルール洗練}

本節では，複数の事例を同時に提示した場合，提 示された事例によって, ルールベースの洗練後の推論 結果及びその他の事例に対する推論結果がどのような 影響を受けるかを検討した。

\section{a)すべての事例を同時に提示した場合}

8 事例をすべて同時に提示し, ルールベースの洗練 を行った。 その後, 各事例に対する損傷要因の可能性 
を推定したそその推論結果を図-7に示した．図中に は, 比較のため既存システムの推論結果及び単独事例 を提示した場合の結果も併せて示した. 更に, 既存シ ステムと本システムによる推論結果の誤差を式(15)で 算定し図-8に示した.

これらの結果から，すべての事例を同時に提示し てルールベースを洗練した場合，単独事例による洗練 より，教師データと一致する割合は低くなった。これ は, すべての教師データに合致することを目標にルー ルベースが洗練されているために，個々の事例に対す る推定精度が低下していることによる.しかし, 本来, ある時点で得られる情報から決定されるルールベース は 1 つに特定されるべきであり，図-8に示した結果 は, 全事例を教師データとしてただ 1 組のルールベー スを求めたにも関わらず䛊差は小さく，ルール洗練の 効果が顕著であるといえる。このことは, 既存システ ムの推論性能を取り込んだ推論システムを, きわめて 容易に構築できることを示している.

b) 損傷場所が同一の事例を同時に提示した場合

損傷要因と損傷種類の因果関係が損傷場所の影響を

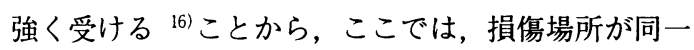
の事例のみを同時に提示してルールベースを洗練した.

損傷場所の一致する事例は, 表-2 より事例 1，4,

$5,6,7$ 及び 8 の計 6 つである.これらはすべてハ ンチ部付近に損傷を生じた事例であり，これらをすべ て同時に提示してルールベースの洗練を行った. 例と して, 事例 4 の推論結果を図-9 に示した. 図中には, 比較のために, 8 つの事例を同時に提示した結果と教 師デー夕も併せて示した。更に, 各事例の推論結果と 教師データとの誤差を式(15)で算定し, 図-10 に示し た。

これらの結果から, 損傷場所の情報が異なる事例 2 及び 3 を提示しない場合と, それらも同時に提示し た場合(図-8)を比べると, 当該場所に対する教師デー 夕との一致度は同程度であることが分かる．それに対 して, 損傷場所の異なる事例 2 及び 3 に対する推論 結果の䛊差は未洗練の場合(図-4)よりも更に大きい.

次に, これら 6 つの事例から 5 つの事例を選択し, それらを用いてルールベースを洗練した，事例の組み 合わせは以下に示す 6 パターンとなる.

Ex.6-8:事例 1, 事例 4, 事例 5, 事例 6, 事例 7

Ex.6-7:事例 1, 事例 4, 事例 5, 事例 6, 事例 8

Ex.6-6:事例 1, 事例 4, 事例 5, 事例 7, 事例 8

Ex.6-5:事例 1, 事例 4, 事例 6, 事例 7, 事例 8

Ex.6-4:事例 1, 事例 5, 事例 6, 事例 7, 事例 8

Ex.6-1:事例 4, 事例 5, 事例 6, 事例 7, 事例 8

ここで, 例えば, Ex.6-8 は 6 事例の中から事例 8 を除いたものである.
各パターンの事例を用いてルールベースを洗練し， それぞれ提示事例に含まれない事例について推論結果 を求め, 教師データとの䛊差を算定し図-11 に示した。

事例として提示していない事例に対する推論結果 を見ると，すべての事例を推定した場合(図-8) や損 傷場所が同一のすべての事例を提示した場合(図-10) に比べると, 誤差が同程度のもの(事例 4,6,7) と大き く開いているもの(事例 1,5,8)がある. しかし、ルー ルベース洗練をしない場合(図-4)に比べれば，明らか に推定精度は向上している．このことは，提示する事 例の質が良い場合には，未提示事例に対しても良い推 論結果を与える機能を本システムがもっていることを 示すものである.

\section{6. 結論}

本研究では, 仮説と仮説間の関係を構成要素とす る相互結合ネットワークで表現されたルールベース洗 練機能付汎用型推論システムを構築した. 本推論シス テムは, エキスパートシステムの知識をルール化する ことにより, 通常の推論を行えるばかりではなく, 具 体事例に対する既存システムの推論結果を教師データ として用いることによって, ルールベースを洗練する ことができる．適用例としては，三上・田中により開 発された道路橋 $\mathrm{RC}$ 床版の損傷要因推定エキスパート システムのルールベースを用いて本システムの性能を 検討した. 得られた主な結論を以下に示す.

（1）ルールベースを確定情報として，損傷要因の可能 性を推定した場合, 傾向としては損傷要因の可能 性の大小の分類が可能である.

(2) 既存システムの推論結果を確定的な教師データと して提示してルールベースを洗練し，その後，洗 練されたルールベースを用いて損傷要因を推定し た場合,

・単独事例を提示してルールベースを洗練すると 各事例の推論結果が教師データとほほ一致する。

・複数事例を同時に提示した場合, 提示された事 例によって，ルールベースの推論結果及びその 他の事例に対する推論結果は影響される.

・複数事例をすべて同時に提示しても, 単独事例 提示の場合と比べて推定精度の悪化は著しくな い.

・未提示事例に対する推論では, 洗練のための教 師データの良否が推論精度に強く影響する.

このように本論文で提案した手法を用いることによ つて既存システムと同等の推論性能をもつルールベー スシステムを容易に構築することができる．また，提 示する事例が適切に選択されれば, 未提示事例の推定 
精度を確保することが可能である.今後の課題として, 複数のルールベースシステムの機能を併せ持つシステ ムの構築とそれによる知識の共有・再利用を計ること が挙げられる.

謝辞: 本研究を行うに当たり, 関西大学の三上市蔵教 授並びに田中成典助教授に有益なご助言を頂きました。

\section{参考文献}

1) 矢田光治:AI 入門, オーム社, 1987.5.

2)古田 均, King-Sun Fu - James. T.P.Yao:知識工学-工 キスパートシステムーの構造工学への応用, 土木学会誌, pp. 28-33, 1985.9.

3)溝口理一郎: 知識の共有と再利用研究の現状と動向, 人工 知能学会誌, Vol.9, No.1, pp. 3-9, 1994.1.

4)串田守可, 宮本文穂: 橋梁診断システム構築における知識 獲得手法の提案, 土木学会論文集, No. 513/I-31, pp. 139-150, 1995. 4 .

5)白石成人, 古田 均, 中林正司, 細谷 学: 学習機能を持 った橋梁設計支援システムに関する研究, 構造工学論文 集, Vol.36A, pp. 525-535, 1990.3.

6)田中成典, 三上市蔵, 前田秀典, 小林 篤: 鋼道路橋の疲 労亀裂に対する補修・補強方法の類推推論選定システム, 構造工学論文集, Vol.42A, pp.421-432, 1996.3.

7)小林重信: 事例べース推論の現状と展望, 人工知能学会誌, Vol.7, №.4, pp. 559-565, 1992.7.

8)中村秀治, 松浦真一, 松井正一, 寺野隆雄: 知識工学的手 法に基づく水力鋼構造物の寿命予測, 土木学会論文集, №. 368/I-5, pp.301-310, 1986. 4 .
9）中村秀治, 松浦真一, 寺野隆雄, 篠原靖志: 水力鋼構造 物の寿命予測エキスパート・システムとその適用，士 木学会論文集, №.374/I-6, pp.513-521，1986. 10.

10) 宮本文穂, 森川英典, 古川正典: 知識更新機能を有す るコンクリート橋診断エキスパートシステムの開発,

構造工学論文集, Vol.38A, pp.543-556, 1992.3.

11) 宮本文穂, 森川英典, 益成一郎, 古川正典: 橋梁診断 エキスパートシステムにおける知識の更新手法，構 造工学論文集, Vol.37A, pp.643-654, 1991.3.

12) 三上市蔵, 田中成典，倉地 晶：鋼橋疲労損傷の補 修方法選定のための学習機能のあるニューラルネッ トワークシステム, 構造工学論文集, Vol.38A, pp. 543 $-556,1992.3$.

13) 三上市蔵, 田中成典, 土田貴敬, 北岸秀一: ネット ワークモデルによる知識生成機能を持った損傷型推 論エンジン, 土木学会論文集, №.453/VI-17, pp. 41 $-50,1992.9$.

14) 三上市蔵, 田中成典, 北岸秀一, 神戸和仁：鋼橋疲 労損傷の補修方法選定システムにおける知識の再利 用, 構造工学論文集, Vol.38A, pp. 529-542, 1992.3.

15) 田中成典, 三上市蔵, 前田秀典, 小林 篤: 事例ベス推論とルールベース推論を併用した鋼橋疲労損傷 の補修方法選定システムの開発, Vol.41A, pp. 575-586, 1995. 3.

16) J. デイホフ, 桂井 治訳 : ニューラルネットワークア 一キテクチャ入門, 森北出版株式会社, 1993.9.

17) 三上市蔵, 松井繁之, 田中成典, 新内康芳：道路橋 鉄筋コンクリート床版の損傷要因推定のためのルー ルとフレームによる知識ベース・エキスパートシス テム, 構造工学論文集, pp.551-562, 1988.3.

(1997.7.8 受付)

\title{
AN EXPERT SYSTEM FOR CRACK DIAGNOSIS OF DAMAGED BRIDGE SLABS WITH KNOWLEDGE REFINEMENT FUNCTION BASED ON CASE-BASES
}

\section{Masaru MINAGAWA, Shigeru SATOH and Takekazu KAMITANI}

\begin{abstract}
Knowledge acquisition is one of the most crucial requirement for expert systems, because knowledge is usually based on experiences or subjective judgement of engineers. In this paper, a knowledge refinement method is proposed for crack diagnostic expert system. The inference engine is constructed for a reciprocal network based on min-max composition algorithm. Knowledge refinement function is installed into the engine by using the concept of back propagation algorithm usually used for layer-type neural networks. The inference and refinement method are applied to the rule-base system for crack diagnosis of damaged bridge slabs. It is confirmed that existing knowledgebase can be easily transferred to another system for rule-base shearing by using the algorithm proposed here.
\end{abstract}

